\title{
Financial integration and emerging markets capital structure
}

\author{
Brian M. Lucey ${ }^{\mathrm{a}, \mathrm{b}, *}$, QiYu Zhang ${ }^{\mathrm{a}}$ \\ ${ }^{a}$ School of Business and Institute for International Integration Studies, Trinity College Dublin, College Green, Dublin 2, Ireland \\ ${ }^{\mathrm{b}}$ Caledonian Business School, Glasgow Caledonian University, Glasgow, Cowcaddens Road, Glasgow G4 OBA, Scotland, UK
}

\section{A R T I C L E I N F O}

\section{Article history:}

Received 26 April 2010

Accepted 5 October 2010

Available online 25 October 2010

\section{JEL classification:}

F30

F36

G15

G32

\section{Keywords:}

Financial integration

Emerging market firms

Corporate leverage

Debt maturity

Emerging markets

Capital structure

Integration

\begin{abstract}
A B S T R A C T
This paper investigates the impact of country-level financial integration on corporate financing choices in emerging economies. Examining 4477 public firms from 24 countries, we find that corporate leverage is positively related to credit market integration and negatively related to equity market integration. As integration proceeds to higher levels, high-growth firms seem to obtain more debt than low-growth firms; large firms seem to obtain more debt - especially long-term debt - and issue more equity than small firms. Also, there is evidence that firms are able to borrow more funds in countries with more efficient legal systems during integration process.
\end{abstract}

() 2010 Published by Elsevier B.V.

\section{Introduction}

Since the late 1980s, the openness of domestic financial markets to foreign investors and institutions is a key structural change in emerging economies. The economic implications of this integration have attracted substantial research efforts. Many papers have documented the positive impact of financial integration at the country level, such as decreased cost of capital (Bekaert and Harvey, 2000; Henry, 2000a; Kim and Singal, 2000), higher economic growth (Bekaert et al., 2001a, b) and greater private investments (Henry, 2000b). The factors that drive these macro-level changes could also affect various metrics of emerging market firms. Among others, a group of literature has shown the relation between financial integration and capital structure decisions. Mitton (2006) shows that firm-specific openness to foreign equity investors is associated with lower leverage. Schmukler and Vesperoni (2006) find that by accessing international equity and bond markets, firms increase their long-term debt and extend their debt maturity. However,

\footnotetext{
* Corresponding author at: School of Business and Institute for International Integration Studies, Trinity College Dublin, College Green, Dublin 2, Ireland. Tel.: +3531 8961522; fax: +35316799503.

E-mail addresses: blucey@tcd.ie (B.M. Lucey), qzhang@tcd.ie (Q. Zhang).
}

market liberalization at the country level decreases the use of long-term debt, and debt maturity shifts to shorter term. Ağca et al. (2007) show that credit market integration results in higher leverage but shorter debt maturity in developing countries. Focusing on Eastern European firms, Giannetti and Ongena (2009) find that foreign bank lending stimulates the use of financial debt although the effect is dampened for small firms.

In this paper, we study the effect of financial integration on corporate leverage and debt maturity in emerging markets. Our study is complementary to the ones cited above but differs from them in several aspects. First, our empirical models emphasize the effects of both credit market integration and equity market integration. Doing this matches the debt and equity component of capital structure. Prior works tend to account for either credit or equity. The studies conducted by Ağca et al. and Giannetti and Ongena focus on the credit side, while the study by Mitton only looks at the equity side. Ignoring either side risks a misinterpretation of estimation results. For instance, if one finds that increased credit market integration does not impact leverage, this could be due to the fact that the level of equity market integration increases as well, offsetting the effect of credit market integration. Alternatively, although the expected effect of one type of integration (either credit or equity market) might be found, completeness suggests 
that both types be incorporated in the model. The reason is that different types of financial integration can proceed simultaneously and therefore interact with each other. Hence, both credit and equity sides should be accounted for to obtain a complete picture. Second, apart from financial integration, we consider a wide range of firm- and country-level determinants of financing choices. Third, we propose a number of interactive effects of financial integration with firm and country characteristics. Interaction analysis allows us to assess whether integration has facilitated the financing of firms in need of capital. Also, we are able to see under what conditions the expected effects of financial integration would be either strengthened or attenuated. Last, in comparison with others, we construct a relatively large sample having more than 4000 public firms from 24 emerging economies during the period 1995-2007.

Our results show that higher levels of credit market integration result in higher leverage and that greater equity market integration leads to lower leverage. The evidence on debt maturity is relatively unclear. Particularly, we find that when the degree of financial integration increases, firms with high growth opportunities seem to borrow more funds than low-growth firms; from integration, large firms are likely to obtain more debt - especially long-term debt - and issue more equity than small firms. There is also evidence showing that firms are able to borrow more funds in countries with more efficient legal systems during the integration process. Thus, our work demonstrates that financial integration does have an impact on the capital structure of emerging markets by affecting factors related to corporate financing. More importantly, different firm and institutional characteristics can lead to different significance and magnitude of the effects.

The remainder of the paper is structured as follows. Section 2 discusses theoretical underpinnings and develops the hypotheses. Section 3 describes the sample and variables. Section 4 presents the regression results. The concluding remarks are given in the final section.

\section{Financial integration and corporate financing: hypotheses development}

\subsection{Main hypotheses}

Previous works suggest two interrelated channels by which financial integration can influence corporate financing choices. First, financial integration improves the availability of financial services in the domestic financial market, enhances a country's access to international capital and allows foreign equity ownership (e.g., Levine, 1996; Obstfeld, 1998; Giannetti et al., 2002). The new scenarios expand firms' financing options, especially when their home countries have limited capital. The emergence of extra financing resources may thus result in a change in capital structure.

Second, theories suggest that we should expect a decline in the cost of capital as financial integration proceeds to higher levels. ${ }^{1}$ Related literature has provided evidence to support the prediction. For example, Bekaert and Harvey (2000), Henry (2000a) and Kim and Singal (2000) report a decrease in the cost of equity after equity market liberalization using a market level analysis. ${ }^{2}$ Chari and Henry (2004) find that emerging market firms that become investible for foreign investors, experience a positive stock price revaluation of

\footnotetext{
1 The decline could be driven by some beneficial outcomes of integration such as international risk sharing, diversification potentials, increased competition and efficiency of financial markets and institutions, enhanced corporate governance, and improved information environment (e.g., Stulz, 1999; Errunza and Miller, 2000; Claessens et al., 2001; Giannetti et al., 2002; Doidge et al., 2004; Bae et al., 2006).

2 These studies assume that financial integration takes place upon liberalization announcement. However, one must be aware that liberalization does not necessarily render immediate integration.
}

$15.1 \%$ on average, suggesting a reduction in the cost of equity. Patro and Wald (2005) find that firms' stock returns increase during liberalization and that most firms have lower mean returns and dividend yields after liberalization. In the spirit of the above arguments, firms can adjust their use of debt and equity financing as a result of expanded financing resources and reduced cost of debt and equity capital from financial integration. Thus, we test the following hypothesis:

H1a. The degree of credit market integration is positively associated with corporate leverage in emerging markets.

H1b. The degree of equity market integration is negatively associated with corporate leverage in emerging markets.

Regarding debt maturity, we argue that emerging market firms are likely to obtain additional debt finance due to credit market integration, but primarily at short maturities. The main reason is that the weak financial and legal institutions in developing countries will force creditors to use short-term debt to monitor and discipline borrowers' behavior. ${ }^{3}$ Schmukler and Vesperoni (2006) argue that if foreign creditors are more risk averse than domestic investors, the debt maturity structure would shift to the short term because foreign creditors would charge emerging market borrowers a higher risk premium on long-term issues than domestic investors. It is also possible that, as noted by Ağca et al. (2007), increased competition from foreign financial intermediaries and markets is likely to make domestic lenders shorten debt maturity as existing relationship lending can be broken as arms-length finance becomes more prominent. Regarding the equity side, market integration would make equity finance more desirable. Firms could switch from longterm debt to equity since both are long-term financing. Thus, we test the following hypothesis:

H2a. The degree of credit market integration is negatively associated with debt maturity in emerging markets.

H2b. The degree of equity market integration is negatively associated with debt maturity in emerging markets.

\subsection{Interactive effects of financial integration on corporate financing}

The preceding discussions revolve around the direct effects of financial integration on financing choices. In this section, we discuss conditions under which financial integration can exert differential effects. These conditions can be grouped into three categories, namely, growth opportunity of firms, firm size and the efficiency of a country's legal system.

Our first interactive prediction is that firms with greater external financing needs would benefit more from financial integration. Rajan and Zingales (1998) find that industrial sectors that are more in need of external financing grow faster in more financially developed countries. Their evidence suggests that financial development can facilitate external financing for a firm. In our terminology, financial integration leads to greater financial depth and lower financing costs. This means that more external capital is available than before and at a lower cost, and a fall in a country's cost of capital can transform some negative net present value (NPV) projects into positive NPV projects in the long run. These improvements are likely to motivate firms' financing and investments into new projects and assets. Indeed, Henry (2000b) finds abnormally high

\footnotetext{
${ }^{3}$ It is argued that short-term debt makes it difficult for borrowers to defraud creditors (e.g., Diamond 1991, 1993; Rajan, 1992). Short-term debt is also used when it is costly to enforce debt contracts (Diamond, 2004)
} 
growth rates of private investments following liberalization in developing countries. The results of Gupta and Yuan (2009) suggest that industries that are more externally dependent and face better growth opportunities grow faster following liberalization in emerging economies. Now, if we consider that the willingness of raising capital increases with firms' growth opportunities, we can test the following hypotheses:

H3a. The positive impact of credit market integration on corporate leverage is more pronounced for high-growth firms than lowgrowth firms.

H3b. The negative impact of equity market integration on corporate leverage is more pronounced for high-growth firms than low-growth firms.

H4. The negative impact of credit market integration on debt maturity is more pronounced for high-growth firms than lowgrowth firms.

It is then natural to ask whether all capital-seeking companies could benefit equally from financial integration. The answer seems to be "No." Stiglitz and Weiss (1981) develop models of equilibrium credit rationing under moral hazard and adverse selection problems. Their models suggest that market friction can hinder capital from flowing to firms with profitable investment projects. Merton (1987) notes that investors invest in the securities familiar to them. Hence, it is reasonable to presume that lenders and investors prefer firms with rich information available to outside stakeholders. Many empirical studies use firm size as a proxy for information availability and provide valuable insights. Addressing the home bias puzzle, Kang and Stulz (1997) find that foreign investors hold disproportionately more shares in larger firms. Bailey et al. (1999) identify the price premiums of unrestricted shares investable for foreigners over shares restricted to local investors. They find that good information in the form of large firm size can partly explain the premiums. The results of Berger et al. (2001) suggest that foreign-owned banks are less likely than domestically owned banks to lend to informationally opaque small firms. Christoffersen et al. (2006) find that large firms tend to have large price revaluation effects, while small firms exhibit small revaluation effects after liberalization. Mian (2006) finds that greater geographical and cultural distances between a foreign bank's headquarters and local branches lead to the avoidance of lending to informationally difficult firms such as small firms, even though these firms can be fundamentally sound. All these arguments predict that in a global-finance environment, large firms have better access to external financing, especially long-term financing. Thus, we test the following hypotheses:

H5a. The positive impact of credit market integration on corporate leverage is more pronounced for large firms than small firms.

H5b. The negative impact of equity market integration on corporate leverage is more pronounced for large firms than small firms.

H6. The negative impact of credit market integration on debt maturity is less pronounced for large firms than small firms.

Not only do creditability and information richness of a company play an important role in external financing, but the quality of the legal system facing the company does, too. A series of works by La Porta et al. (1997, 1998 and 2000) has established links between legal variables and economic/financial outcomes. They suggest that the contents of law and legal enforcement matter in protecting the interests of creditors and shareholders, and thereby are of great importance to financial market development. Relating law to banking, Qian and Strahan (2007) find that foreign banks are rather sensitive to the legal and institutional environments because their willingness of lending to local firms is inversely associated with creditor protection. Beck et al. (2008) find that firms in countries with poor institutions use less external financing, especially bank financing, and that protection of property rights increases external financing and the effect is more significant for small firms than big firms. Based on these points, the impact of financial integration on financing outcomes should be more significant in countries with superior legal systems. Thus, we test the following hypotheses:

H7a. The positive impact of credit market integration on corporate leverage is more pronounced in countries with more efficient legal systems.

H7b. The negative impact of equity market integration on corporate leverage is more pronounced in countries with more efficient legal systems.

H8. The negative impact of credit market integration on debt maturity is less pronounced in countries with more efficient legal systems.

\section{Sample and variables}

\subsection{Sample selection and firm-level variables}

Our dataset consists of public firms from 24 emerging markets covering the period from 1995 to $2007 .{ }^{4}$ Following common practice in capital structure studies, we exclude firms in financial sectors and utilities. ${ }^{5}$ We require selected firms to have at least 4 years of data for corporate leverage and debt maturity variables. The selection process ends up with a sample of 4477 firms. Table 1 shows the distribution of these firms across countries.

Annual data on firm-level variables are collected from the Worldscope database. We use two measures of corporate leverage. One is the book-value leverage (BLEV), defined as the ratio of total debt (Worldscope item 03255) over total assets (Worldscope item 02999). The other is the market-value leverage (MLEV), defined as the ratio of total debt over market value of total assets, which is calculated as total assets minus book value of total shareholder equity (Worldscope item 03995) plus market value of equity (Worldscope item 08001). Debt maturity (DMAT) is measured as the ratio of long-term debt (Worldscope item 03251) over total debt.

Capital structure literature suggests several firm-level factors that affect corporate leverage and debt maturity. ${ }^{6}$ These factors are as follows. SIZE: Firm size is defined as the natural logarithm of total assets. TANG: Asset tangibility is defined as the ratio of net property, plant and equipment (Worldscope item 02501) over total assets. GROWTH: Growth opportunity is defined as total assets minus total shareholder equity plus market value of equity

\footnotetext{
${ }^{4}$ The emerging markets in our sample are those categorized by the MSCI Emerging Markets Indices 2007. The source categorizes 25 capital markets as emerging markets. We omit China because the country is still transitioning towards a marketoriented economy. The firms in the sample are those included in the constituent list of the Worldscope database.

5 To identify the industry that a firm belongs to, we use the FTSE/DJ Industry Classification Benchmark under which the equity is classified.

${ }^{6}$ For firm-level determinants, we follow previous works such as DeAngelo and Masulis (1980), Barclay and Smith (1995), Rajan and Zingales (1995), Booth et al (2001), Brounen et al. (2006), De Jong et al. (2008), and Fan et al. (2010).
} 
Table 1

Descriptive statistics of firm-level variables.

\begin{tabular}{|c|c|c|c|c|c|c|c|c|c|}
\hline Country & Number of firms & BLEV & MLEV & DMAT & SIZE & TANG & GROWTH & PROFIT & NDTS \\
\hline Argentina & 50 & $\begin{array}{c}0.239 \\
(0.229)\end{array}$ & $\begin{array}{c}0.255 \\
(0.239)\end{array}$ & $\begin{array}{c}0.436 \\
(0.472)\end{array}$ & $\begin{array}{c}12.709 \\
(12.428)\end{array}$ & $\begin{array}{c}0.472 \\
(0.490)\end{array}$ & $\begin{array}{c}1.069 \\
(0.945)\end{array}$ & $\begin{array}{c}0.061 \\
(0.059)\end{array}$ & $\begin{array}{c}0.053 \\
(0.046)\end{array}$ \\
\hline Brazil & 184 & $\begin{array}{c}0.254 \\
(0.242)\end{array}$ & $\begin{array}{c}0.267 \\
(0.241)\end{array}$ & $\begin{array}{c}0.477 \\
(0.522)\end{array}$ & $\begin{array}{c}13.725 \\
(13.606)\end{array}$ & $\begin{array}{c}0.413 \\
(0.405)\end{array}$ & $\begin{array}{c}1.103 \\
(0.943)\end{array}$ & $\begin{array}{c}0.073 \\
(0.069)\end{array}$ & $\begin{array}{c}0.046 \\
(0.038)\end{array}$ \\
\hline Chile & 105 & $\begin{array}{c}0.214 \\
(0.215)\end{array}$ & $\begin{array}{c}0.208 \\
(0.186)\end{array}$ & $\begin{array}{c}0.537 \\
(0.609)\end{array}$ & $\begin{array}{c}18.451 \\
(18.499)\end{array}$ & $\begin{array}{c}0.500 \\
(0.499)\end{array}$ & $\begin{array}{c}1.219 \\
(1.046)\end{array}$ & $\begin{array}{c}0.066 \\
(0.062)\end{array}$ & $\begin{array}{c}0.041 \\
(0.036)\end{array}$ \\
\hline Colombia & 25 & $\begin{array}{c}0.130 \\
(0.093)\end{array}$ & $\begin{array}{c}0.163 \\
(0.123)\end{array}$ & $\begin{array}{c}0.515 \\
(0.569)\end{array}$ & $\begin{array}{c}20.198 \\
(20.371)\end{array}$ & $\begin{array}{c}0.487 \\
(0.487)\end{array}$ & $\begin{array}{c}0.875 \\
(0.753)\end{array}$ & $\begin{array}{c}0.044 \\
(0.042)\end{array}$ & $\begin{array}{c}0.033 \\
(0.027)\end{array}$ \\
\hline Czech & 33 & $\begin{array}{c}0.198 \\
(0.189)\end{array}$ & $\begin{array}{c}0.254 \\
(0.235)\end{array}$ & $\begin{array}{c}0.461 \\
(0.429)\end{array}$ & $\begin{array}{c}15.625 \\
(15.295)\end{array}$ & $\begin{array}{c}0.553 \\
(0.569)\end{array}$ & $\begin{array}{c}0.876 \\
(0.766)\end{array}$ & $\begin{array}{c}0.015 \\
(0.026)\end{array}$ & $\begin{array}{c}0.065 \\
(0.061)\end{array}$ \\
\hline Egypt & 24 & $\begin{array}{c}0.285 \\
(0.289)\end{array}$ & $\begin{array}{c}0.231 \\
(0.188)\end{array}$ & $\begin{array}{c}0.543 \\
(0.640)\end{array}$ & $\begin{array}{c}14.397 \\
(14.159)\end{array}$ & $\begin{array}{c}0.513 \\
(0.498)\end{array}$ & $\begin{array}{c}1.544 \\
(1.242)\end{array}$ & $\begin{array}{c}0.106 \\
(0.099)\end{array}$ & $\begin{array}{c}0.038 \\
(0.030)\end{array}$ \\
\hline Hungary & 28 & $\begin{array}{c}0.175 \\
(0.170)\end{array}$ & $\begin{array}{c}0.186 \\
(0.159)\end{array}$ & $\begin{array}{c}0.413 \\
(0.375)\end{array}$ & $\begin{array}{c}17.056 \\
(16.897)\end{array}$ & $\begin{array}{c}0.439 \\
(0.445)\end{array}$ & $\begin{array}{c}1.202 \\
(1.023)\end{array}$ & $\begin{array}{c}0.036 \\
(0.035)\end{array}$ & $\begin{array}{c}0.053 \\
(0.049)\end{array}$ \\
\hline India & 437 & $\begin{array}{c}0.285 \\
(0.296)\end{array}$ & $\begin{array}{c}0.260 \\
(0.220)\end{array}$ & $\begin{array}{c}0.617 \\
(0.669)\end{array}$ & $\begin{array}{c}15.805 \\
(15.693)\end{array}$ & $\begin{array}{c}0.394 \\
(0.386)\end{array}$ & $\begin{array}{c}1.720 \\
(1.260)\end{array}$ & $\begin{array}{c}0.094 \\
(0.089)\end{array}$ & $\begin{array}{c}0.036 \\
(0.032)\end{array}$ \\
\hline Indonesia & 152 & $\begin{array}{c}0.278 \\
(0.263)\end{array}$ & $\begin{array}{c}0.284 \\
(0.240)\end{array}$ & $\begin{array}{c}0.412 \\
(0.402)\end{array}$ & $\begin{array}{c}20.013 \\
(20.016)\end{array}$ & $\begin{array}{c}0.411 \\
(0.383)\end{array}$ & $\begin{array}{c}1.235 \\
(1.017)\end{array}$ & $\begin{array}{c}0.078 \\
(0.073)\end{array}$ & $\begin{array}{c}0.045 \\
(0.039)\end{array}$ \\
\hline Israel & 106 & $\begin{array}{c}0.240 \\
(0.219)\end{array}$ & $\begin{array}{c}0.201 \\
(0.163)\end{array}$ & $\begin{array}{c}0.512 \\
(0.560)\end{array}$ & $\begin{array}{c}13.670 \\
(13.733)\end{array}$ & $\begin{array}{c}0.273 \\
(0.209)\end{array}$ & $\begin{array}{c}1.512 \\
(1.246)\end{array}$ & $\begin{array}{c}0.028 \\
(0.042)\end{array}$ & $\begin{array}{c}0.041 \\
(0.035)\end{array}$ \\
\hline Jordan & 11 & $\begin{array}{r}0.153 \\
(0.142)\end{array}$ & $\begin{array}{c}0.124 \\
(0.103)\end{array}$ & $\begin{array}{c}0.497 \\
(0.687)\end{array}$ & $\begin{array}{c}11.820 \\
(12.082)\end{array}$ & $\begin{array}{c}0.346 \\
(0.307)\end{array}$ & $\begin{array}{c}1.690 \\
(1.416)\end{array}$ & $\begin{array}{c}0.088 \\
(0.072)\end{array}$ & $\begin{array}{c}0.043 \\
(0.041)\end{array}$ \\
\hline Korea & 682 & $\begin{array}{c}0.277 \\
(0.275)\end{array}$ & $\begin{array}{c}0.310 \\
(0.302)\end{array}$ & $\begin{array}{c}0.381 \\
(0.366)\end{array}$ & $\begin{array}{c}19.194 \\
(19.000)\end{array}$ & $\begin{array}{c}0.368 \\
(0.367)\end{array}$ & $\begin{array}{c}1.043 \\
(0.888)\end{array}$ & $\begin{array}{c}0.053 \\
(0.052)\end{array}$ & $\begin{array}{c}0.039 \\
(0.033)\end{array}$ \\
\hline Malaysia & 630 & $\begin{array}{c}0.227 \\
(0.210)\end{array}$ & $\begin{array}{c}0.230 \\
(0.197)\end{array}$ & $\begin{array}{c}0.363 \\
(0.300)\end{array}$ & $\begin{array}{c}12.699 \\
(12.485)\end{array}$ & $\begin{array}{c}0.405 \\
(0.399)\end{array}$ & $\begin{array}{c}1.196 \\
(0.985)\end{array}$ & $\begin{array}{c}0.045 \\
(0.045)\end{array}$ & $\begin{array}{c}0.032 \\
(0.028)\end{array}$ \\
\hline Mexico & 100 & $\begin{array}{c}0.226 \\
(0.220)\end{array}$ & $\begin{array}{c}0.220 \\
(0.190)\end{array}$ & $\begin{array}{c}0.614 \\
(0.714)\end{array}$ & $\begin{array}{c}15.641 \\
(15.753)\end{array}$ & $\begin{array}{c}0.492 \\
(0.545)\end{array}$ & $\begin{array}{c}1.243 \\
(1.084)\end{array}$ & $\begin{array}{c}0.082 \\
(0.083)\end{array}$ & $\begin{array}{c}0.038 \\
(0.034)\end{array}$ \\
\hline Morocco & 14 & $\begin{array}{c}0.081 \\
(0.036)\end{array}$ & $\begin{array}{c}0.054 \\
(0.014)\end{array}$ & $\begin{array}{c}0.266 \\
(0.019)\end{array}$ & $\begin{array}{c}15.119 \\
(14.871)\end{array}$ & $\begin{array}{c}0.309 \\
(0.256)\end{array}$ & $\begin{array}{c}2.068 \\
(1.606)\end{array}$ & $\begin{array}{c}0.121 \\
(0.152)\end{array}$ & $\begin{array}{c}0.062 \\
(0.059)\end{array}$ \\
\hline Pakistan & 61 & $\begin{array}{c}0.260 \\
(0.230)\end{array}$ & $\begin{array}{c}0.245 \\
(0.189)\end{array}$ & $\begin{array}{c}0.371 \\
(0.331)\end{array}$ & $\begin{array}{c}15.189 \\
(15.262)\end{array}$ & $\begin{array}{c}0.424 \\
(0.401)\end{array}$ & $\begin{array}{c}1.325 \\
(1.103)\end{array}$ & $\begin{array}{c}0.125 \\
(0.115)\end{array}$ & $\begin{array}{c}0.041 \\
(0.038)\end{array}$ \\
\hline Peru & 54 & $\begin{array}{c}0.233 \\
(0.226)\end{array}$ & $\begin{array}{c}0.264 \\
(0.239)\end{array}$ & $\begin{array}{c}0.419 \\
(0.448)\end{array}$ & $\begin{array}{c}12.554 \\
(12.356)\end{array}$ & $\begin{array}{c}0.459 \\
(0.449)\end{array}$ & $\begin{array}{c}1.283 \\
(0.928)\end{array}$ & $\begin{array}{c}0.084 \\
(0.070)\end{array}$ & $\begin{array}{c}0.050 \\
(0.042)\end{array}$ \\
\hline Philippines & 81 & $\begin{array}{c}0.250 \\
(0.242)\end{array}$ & $\begin{array}{c}0.267 \\
(0.232)\end{array}$ & $\begin{array}{c}0.432 \\
(0.460)\end{array}$ & $\begin{array}{c}15.443 \\
(15.435)\end{array}$ & $\begin{array}{c}0.455 \\
(0.460)\end{array}$ & $\begin{array}{c}1.164 \\
(0.944)\end{array}$ & $\begin{array}{c}0.038 \\
(0.033)\end{array}$ & $\begin{array}{c}0.043 \\
(0.036)\end{array}$ \\
\hline Poland & 109 & $\begin{array}{c}0.155 \\
(0.118)\end{array}$ & $\begin{array}{c}0.118 \\
(0.075)\end{array}$ & $\begin{array}{c}0.484 \\
(0.449)\end{array}$ & $\begin{array}{c}12.626 \\
(12.543)\end{array}$ & $\begin{array}{c}0.367 \\
(0.367)\end{array}$ & $\begin{array}{c}1.537 \\
(1.252)\end{array}$ & $\begin{array}{c}0.056 \\
(0.056)\end{array}$ & $\begin{array}{c}0.051 \\
(0.045)\end{array}$ \\
\hline Russia & 43 & $\begin{array}{c}0.220 \\
(0.193)\end{array}$ & $\begin{array}{c}0.208 \\
(0.169)\end{array}$ & $\begin{array}{c}0.530 \\
(0.579)\end{array}$ & $\begin{array}{c}17.487 \\
(17.442)\end{array}$ & $\begin{array}{c}0.581 \\
(0.606)\end{array}$ & $\begin{array}{c}1.431 \\
(1.133)\end{array}$ & $\begin{array}{c}0.090 \\
(0.094)\end{array}$ & $\begin{array}{c}0.057 \\
(0.051)\end{array}$ \\
\hline South Africa & 281 & $\begin{array}{c}0.158 \\
(0.127)\end{array}$ & $\begin{array}{c}0.138 \\
(0.095)\end{array}$ & $\begin{array}{c}0.505 \\
(0.543)\end{array}$ & $\begin{array}{c}13.474 \\
(13.535)\end{array}$ & $\begin{array}{c}0.300 \\
(0.242)\end{array}$ & $\begin{array}{c}1.508 \\
(1.257)\end{array}$ & $\begin{array}{c}0.092 \\
(0.099)\end{array}$ & $\begin{array}{c}0.041 \\
(0.035)\end{array}$ \\
\hline Taiwan & 1067 & $\begin{array}{c}0.241 \\
(0.233)\end{array}$ & $\begin{array}{c}0.229 \\
(0.198)\end{array}$ & $\begin{array}{c}0.348 \\
(0.305)\end{array}$ & $\begin{array}{c}15.340 \\
(15.212)\end{array}$ & $\begin{array}{c}0.338 \\
(0.320)\end{array}$ & $\begin{array}{c}1.366 \\
(1.143)\end{array}$ & $\begin{array}{c}0.053 \\
(0.047)\end{array}$ & $\begin{array}{c}0.037 \\
(0.031)\end{array}$ \\
\hline Thailand & 53 & $\begin{array}{c}0.299 \\
(0.301)\end{array}$ & $\begin{array}{c}0.294 \\
(0.261)\end{array}$ & $\begin{array}{c}0.379 \\
(0.371)\end{array}$ & $\begin{array}{c}14.925 \\
(14.818)\end{array}$ & $\begin{array}{c}0.443 \\
(0.457)\end{array}$ & $\begin{array}{c}1.175 \\
(1.013)\end{array}$ & $\begin{array}{c}0.057 \\
(0.057)\end{array}$ & $\begin{array}{c}0.042 \\
(0.037)\end{array}$ \\
\hline Turkey & 147 & $\begin{array}{c}0.195 \\
(0.162)\end{array}$ & $\begin{array}{c}0.157 \\
(0.117)\end{array}$ & $\begin{array}{c}0.312 \\
(0.236)\end{array}$ & $\begin{array}{c}11.732 \\
(11.575)\end{array}$ & $\begin{array}{c}0.359 \\
(0.349)\end{array}$ & $\begin{array}{c}1.582 \\
(1.271)\end{array}$ & $\begin{array}{c}0.098 \\
(0.087)\end{array}$ & $\begin{array}{c}0.055 \\
(0.048)\end{array}$ \\
\hline Full sample & 4477 & $\begin{array}{c}0.240 \\
(0.225)\end{array}$ & $\begin{array}{c}0.238 \\
(0.199)\end{array}$ & $\begin{array}{c}0.427 \\
(0.422)\end{array}$ & $\begin{array}{c}15.448 \\
(15.185)\end{array}$ & $\begin{array}{c}0.384 \\
(0.374)\end{array}$ & $\begin{array}{c}1.312 \\
(1.055)\end{array}$ & $\begin{array}{c}0.064 \\
(0.060)\end{array}$ & $\begin{array}{c}0.040 \\
(0.034)\end{array}$ \\
\hline
\end{tabular}

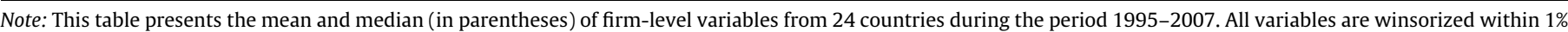

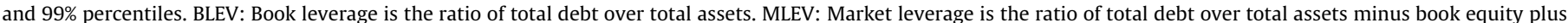

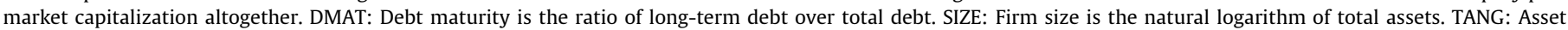

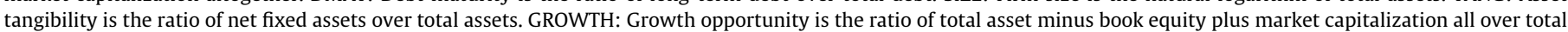

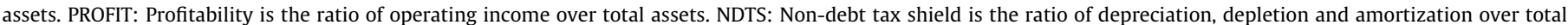
assets.

all over total assets. PROFIT: Profitability is defined as operating income (Worldscope item 01250) over total assets. NDTS: Non-debt tax shield is defined as depreciation, depletion and amortization (Worldscope item 01151) over total assets. To remove outliers, we winsorize all firm-level variables within the $1 \%$ and $99 \%$ percentiles.

Table 1 presents the mean and median values of firm-level variables for each country over the sample period. For the full sample, the mean book-value and market-value leverage ratios are $24 \%$ and $23.8 \%$, respectively, and the mean long-term debt ratio is $42.7 \%$. The highest mean and median book-value leverage ratios are observed in Thailand (29.9\% and 30.1\%), and the lowest are observed in Morocco (8.1\% and 3.6\%). The highest mean and median marketvalue leverage ratios are observed in Korea (31\% and 30.2\%), and the lowest are observed in Morocco (5.4\% and 1.4\%). The highest mean ratio of long-term debt over total debt is observed in India (61.7\%), and the lowest is observed in Morocco (26.6\%). The highest median debt maturity ratio is observed in Mexico (71.4\%), and the lowest is observed in Morocco (1.9\%). The statistics show a wideranging difference in leverage and debt maturity across emerging countries.

\subsection{Financial integration and other country-level variables}

In response to the increasing attention paid to the process of financial integration, numerous measures have been developed to capture the process. The measures are categorized into two major groups, namely, de jure measures and de facto measures. The 

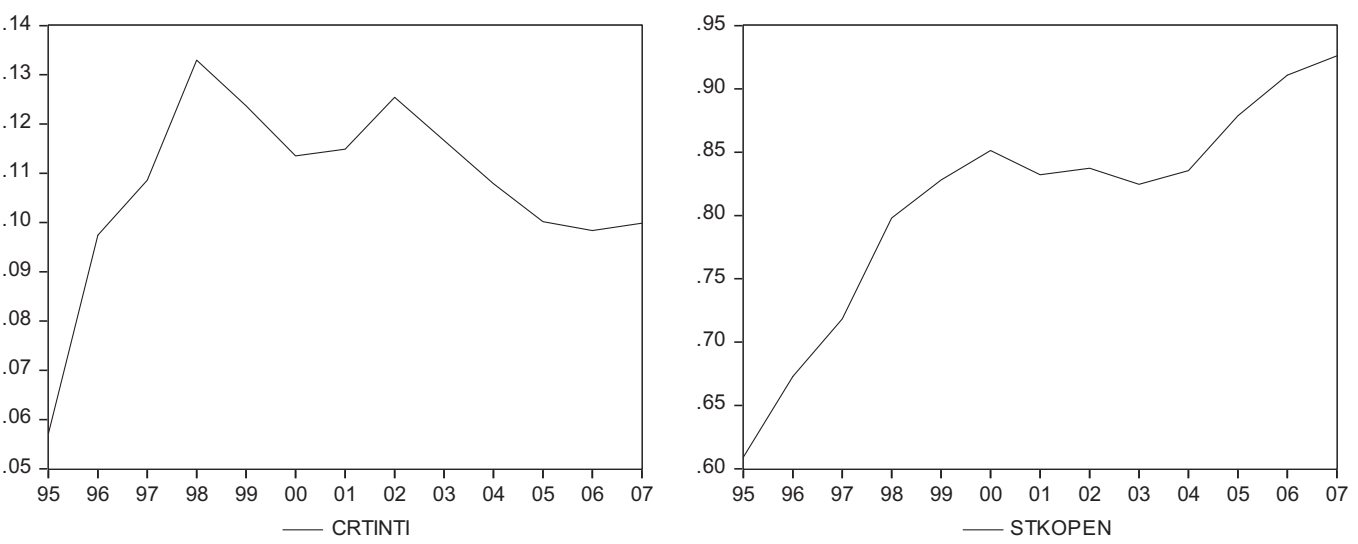

Fig. 1. Time-varying levels of financial integration for the period 1995-2007.

former reflects the changes in policy and legal restrictions on cross-border capital movements, while the latter emphasizes how much in practice a country makes use of international capital markets and sources. Given voluminous candidate measures, we select proper ones based on three considerations. First, the measure(s) should clearly proxy for either credit market or equity market integration. This is to match debt and equity financing of firms. Second, the measure(s) should be time-varying to unveil the dynamic nature of integration. Third, the measure should have sufficient data for most countries during the sample period. To proxy credit market integration (CRTINTI), we use the annual arithmetic average of outstanding international debt securities over GDP (INTLDEBT) and outstanding loans from non-resident banks over GDP (NRBLOAN). The data come from the Financial Structure Database produced by the World Bank and is extensively discussed in Beck and Demirgüç-Kunt (2009). This quantity-based de facto measure gauges the actual use of international credit markets by country.

To proxy equity market integration (STKOPEN), we use a de jure measure proposed by Edison and Warnock (2003). The measure is designed to represent the proportion of domestic equity market that is available to foreign investors and is constructed using the Global index (IFCG) and Investable index (IFCI) of Standard and Poor's/International Finance Corporation (S\&P/IFC). The Global index represents the overall market capitalization of a country, whereas the Investable index represents a subset of the Global index stocks that are available to foreign investors. The ratio of the market capitalization of a country's IFCI and IFCG indices then provides a quantitative measure of stock market openness. A value of one indicates the full market openness, while a value of zero suggests full market segmentation. The measure is calculated on a month-by-month basis and is then averaged across each year to obtain an annual value. The value is an indicator of openness of a country's stock market at a point in time and gives a time-varying picture of openness across years. The traditional method to proxy equity market integration is to use dummy variables based on relevant events such as an official liberalization announcement. However, there are at least two potential drawbacks to relying on this approach. First, even though governments open their financial markets, it is likely that domestic and foreign investors and institutions show little interest to the announcement when it is given. Pinpointing "real" liberalization date is notoriously tricky. Bekaert et al. (2002) specify a set of endogenous liberalization dates for emerging markets, which are usually later than the official dates. Second, the 0/1 measures do not capture the degree of integration over time, but the time-varying nature of integration is widely accepted. In this regard, we believe that Edison and Warnock's measure is more suitable.
Fig. 1 displays the evolution of financial integration of emerging markets over 1995-2007. The relevant values are averaged across countries for each year. We observe some changes in the level of credit/equity market integration over the sample period. As shown in the figure, the degree of credit market integration (CRTINTI) dramatically increases until 1998 and then slows down and declines during the rest of sample period, while equity market integration (STKOPEN) presents an increasing trend over the sample period.

Suggested by prior works (e.g., Demirgüç-Kunt and Maksimovic, 1996, 1999; Gleason et al., 2000; Giannetti, 2003; Ağca et al., 2007; De Jong et al., 2008; Fan et al., 2010), we include a battery of country-level control variables. These variables are as follows. Credit market development (CREDIT) is the ratio of domestic private credit by deposit money banks and other financial institutions over GDP. Stock market development (STOCK) is the ratio of stock market capitalization over GDP. Two macro-economic condition variables are the natural logarithm of GDP per capita at PPP (GDP) and the inflation rate (INFL). With respect to legal institution, we construct a dummy variable (COMMON) that is equal to one if the country adopts the British common law system and zero otherwise. Another legal variable is the index of Legal Structure and Security of Property Rights (LEGAL). The index includes elements such as judicial independence, impartial courts and legal enforcement of contracts. The score ranges from 0 to 10 . Higher scores suggest a more effective legal system. We use the average score across 1995-2006 for each country. Finally, we incorporate two of Hofstede's cultural variables, namely, individualism (IND) and uncertainty avoidance (UAI). ${ }^{7}$ Data on these variables are collected from a variety of sources, such as the Financial Structure Database from the World Bank, Economist Intelligence Unit, IMF International Financial Statistics, DGBAS, La Porta et al. (1998), Economic Freedom of the World-2008 Annual Report, and Hofstede's cultural dimensions website.

Table 2 provides the details and summary statistics of all country-specific variables. Of particular interest are the financial integration variables. We observe the highest credit market integration (CRTINTI) in Argentina (25\%) and Hungary (20\%), and lowest in India (2.7\%) and Pakistan (3.5\%). We observe the highest equity market integration (STKOPEN) in South Africa (99.6\%) and Israel (98.9\%), and lowest in India (42.2\%) and Thailand (50.8\%). Together with Fig. 1, this echoes the recent findings of the heterogeneity of integration across time and country (e.g., Chambet and Gibson, 2008; Akram et al., 2009; Christiansen and Ranaldo,

\footnotetext{
${ }^{7}$ See Hofstede (2001) for the most recent iteration and discussion.
} 
Table 2

Descriptive statistics of country-level variables.

\begin{tabular}{|c|c|c|c|c|c|c|c|c|c|c|c|c|}
\hline Country & CRTINTI & INTLDEBT & NRBLOAN & STKOPEN & CREDIT & STOCK & GDP & INFL & COMMON & LEGAL & IND & UAI \\
\hline Argentina & 0.250 & 0.372 & 0.124 & 0.958 & 0.177 & 0.403 & 8.687 & 0.058 & 0 & 4.832 & 46 & 86 \\
\hline Brazil & 0.106 & 0.121 & 0.093 & 0.887 & 0.337 & 0.377 & 8.370 & 0.120 & 0 & 6.397 & 38 & 76 \\
\hline Chile & 0.133 & 0.069 & 0.213 & 0.884 & 0.686 & 0.937 & 8.640 & 0.042 & 0 & 6.593 & 23 & 86 \\
\hline Colombia & 0.096 & 0.096 & 0.104 & - & 0.304 & 0.210 & 7.899 & 0.109 & 0 & 3.415 & 13 & 80 \\
\hline Czech & 0.083 & 0.033 & 0.144 & 0.775 & 0.472 & 0.233 & 8.967 & 0.046 & 0 & 6.793 & 58 & 74 \\
\hline Egypt & 0.043 & 0.014 & 0.078 & 0.805 & 0.451 & 0.391 & 7.139 & 0.061 & 0 & 5.083 & 38 & 68 \\
\hline Hungary & 0.200 & 0.221 & 0.167 & 0.938 & 0.337 & 0.231 & 8.795 & 0.112 & 0 & 7.210 & 80 & 82 \\
\hline India & 0.027 & 0.012 & 0.046 & 0.422 & 0.291 & 0.443 & 6.288 & 0.062 & 1 & 6.138 & 48 & 40 \\
\hline Indonesia & 0.130 & 0.062 & 0.212 & 0.828 & 0.309 & 0.267 & 6.934 & 0.133 & 0 & 3.940 & 14 & 48 \\
\hline Israel & 0.074 & 0.078 & 0.073 & 0.989 & 0.765 & 0.614 & 9.840 & 0.041 & 1 & 6.815 & 54 & 81 \\
\hline Jordan & 0.096 & 0.068 & 0.126 & - & 0.749 & 1.119 & 7.560 & 0.031 & 0 & 6.235 & - & - \\
\hline Korea & 0.108 & 0.096 & 0.125 & 0.749 & 1.235 & 0.517 & 9.420 & 0.035 & 0 & 6.205 & 18 & 85 \\
\hline Malaysia & 0.178 & 0.170 & 0.196 & 0.922 & 1.213 & 1.628 & 8.412 & 0.026 & 1 & 6.885 & 26 & 36 \\
\hline Mexico & 0.129 & 0.155 & 0.092 & 0.963 & 0.192 & 0.279 & 8.700 & 0.126 & 0 & 5.292 & 30 & 82 \\
\hline Morocco & 0.063 & 0.009 & 0.126 & 0.853 & 0.476 & 0.359 & 7.342 & 0.021 & 0 & 5.557 & 46 & 68 \\
\hline Pakistan & 0.035 & 0.011 & 0.065 & - & 0.236 & 0.194 & 6.386 & 0.069 & 1 & 3.350 & 14 & 70 \\
\hline Peru & 0.077 & 0.069 & 0.091 & 0.879 & 0.213 & 0.303 & 7.794 & 0.046 & 0 & 4.058 & 16 & 87 \\
\hline Philippines & 0.194 & 0.230 & 0.162 & 0.520 & 0.394 & 0.532 & 6.953 & 0.058 & 0 & 4.123 & 32 & 44 \\
\hline Poland & 0.067 & 0.068 & 0.068 & 0.986 & 0.245 & 0.175 & 8.610 & 0.084 & 0 & 6.370 & 60 & 93 \\
\hline Russia & 0.094 & 0.075 & 0.121 & 0.714 & 0.159 & 0.361 & 7.994 & 0.373 & 0 & 4.310 & 39 & 95 \\
\hline South Africa & 0.078 & 0.062 & 0.100 & 0.996 & 1.240 & 1.805 & 8.209 & 0.061 & 1 & 6.043 & 65 & 49 \\
\hline Taiwan & 0.060 & 0.037 & 0.089 & 0.561 & 1.505 & 1.118 & 9.555 & 0.013 & 0 & 6.700 & 17 & 69 \\
\hline Thailand & 0.159 & 0.081 & 0.253 & 0.508 & 1.143 & 0.529 & 7.791 & 0.035 & 1 & 5.913 & 20 & 64 \\
\hline Turkey & 0.099 & 0.072 & 0.132 & 0.985 & 0.162 & 0.227 & 8.457 & 0.478 & 0 & 5.243 & 37 & 85 \\
\hline All countries & 0.098 & 0.095 & 0.125 & 0.815 & 0.554 & 0.552 & 8.114 & 0.093 & 0.250 & 5.563 & 36.174 & 71.652 \\
\hline
\end{tabular}

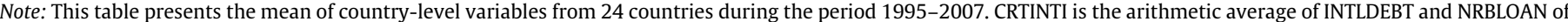

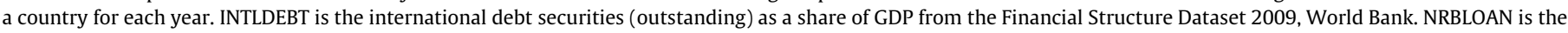

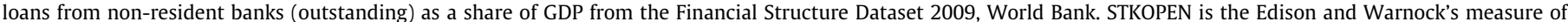

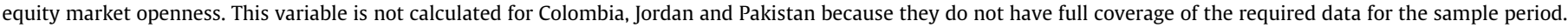

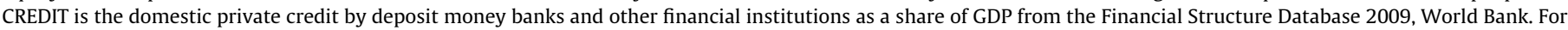

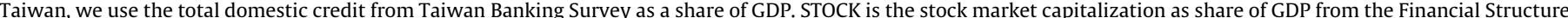

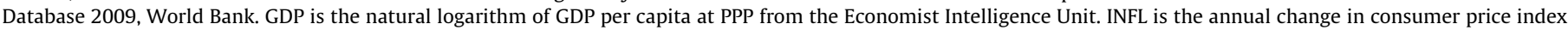

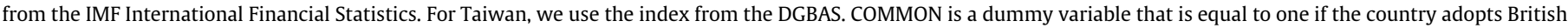

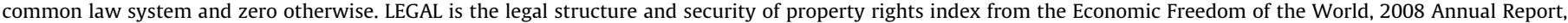

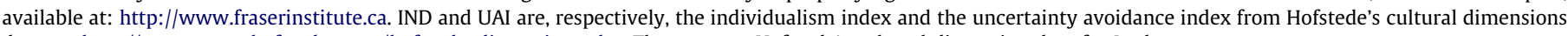
dataset: http://www.geert-hofstedee.com/hofstede_dimensions.php. There are no Hofstede's cultural dimension data for Jordan.

2009; Pukthuanthong and Roll, 2009; Abad et al., 2010; Yu et al., 2010).

Table 3 presents the Pearson correlation coefficients between variables. In Panel A, we consider all firm-level variables. Corporate leverage ratios (BLEV and MLEV) are positively correlated with firm size (SIZE) and asset tangibility (TANG), while negatively correlated with growth opportunity (GROWTH) and profitability (PROFIT). Book-value leverage is positively correlated with non-debt tax shields. Debt maturity ratio (DMAT) is positively correlated with all firm-level explanatory variables. The results are generally consistent with previous studies on determinants of capital structure.

In Panel B of Table 3, we present the coefficients between corporate leverage, debt maturity and country-level variables. We find that book-value leverage is positively correlated with foreign bank loans (NRBLOAN) and negatively correlated with international debt issues (INTLDEBT) and stock market openness (STKOPEN). Market-value leverage is positively correlated with all variables measuring credit market integration and negatively correlated with STKOPEN. Debt maturity is negatively correlated with all financial integration variables. The results basically agree with the predictions of $\mathrm{H} 1 \mathrm{a}, \mathrm{H} 1 \mathrm{~b}, \mathrm{H} 2 \mathrm{a}$ and $\mathrm{H} 2 \mathrm{~b}$, except the negative correlation between INTLDEBT and BLEV. For other country-level variables, corporate leverage is positively correlated with credit market development (CREDIT) and uncertainty avoidance (UAI) of a country, while negatively correlated with stock market development (STOCK), macro-economic conditions (GDP and INFL), legal institutions (COMMON and LEGAL) and individualism (IND) of a country. Debt maturity is positively correlated with INFL, COMMON and IND, while negatively correlated with CREDIT, STOCK, GDP, LEGAL and UAI.

\section{Empirical estimation and results}

\subsection{The empirical model}

We perform the following baseline regression to investigate the causal relation between financial integration and capital structure:

$Y_{i, c, t}=\alpha+a_{c}+a_{s}+a_{t}+\beta_{1}^{\prime}$ FINITI $_{c, t-1}+\beta_{2}^{\prime} X_{i, c, t-1}+\beta_{3}^{\prime} N_{c, t-1}+\varepsilon_{i, c, t}$

where $Y_{i, c, t}$ represents the dependent variables, i.e., corporate leverage and debt maturity. The subscripts $i, c, s$ and $t$ stand for firm, country, industry and year, respectively. $a_{c}, a_{s}$ and $a_{t}$ are country, industry and year dummy variables. FINITI $_{c, t-1}$ denotes the lagged values of financial integration measures, which are the variables of primary interest in this study. $X_{i, c, t-1}$ and $N_{c, t-1}$ stand for lagged vectors of firm- and country-level control variables, respectively. The estimation method is pooled ordinary least squares (OLS) with standard errors clustered by firms to deal with potential serial correlation of residuals for a given firm. All time-variant variables are lagged by 1 year to allow for the non-contemporaneous effects on financing choices. The use of lagged variables also mitigates endogeneity concerns.

\subsection{The effect of financial integration on corporate financing choices}

In Models 1 and 3 of Table 4, we find positive coefficients on CRTINTI at the $1 \%$ level and negative coefficients on STKOPEN at the $1 \%$ level. The results are consistent with the prediction of $\mathrm{H} 1 \mathrm{a}$ and $\mathrm{H} 1 \mathrm{~b}$, that higher credit and equity market integration 
Table 3

Correlation matrix

\begin{tabular}{|c|c|c|c|c|c|c|c|c|c|c|c|c|c|c|}
\hline & & \multicolumn{2}{|c|}{ MLEV } & \multicolumn{2}{|l|}{ DMAT } & \multirow[t]{2}{*}{ SIZE } & \multicolumn{2}{|c|}{ TANG } & \multicolumn{3}{|c|}{ GROWTH } & \multicolumn{2}{|l|}{ PROFIT } & NDTS \\
\hline \multicolumn{14}{|c|}{ Panel A: Firm-level variables } & \\
\hline BLEV & & 0.884 & & 0.173 & & 0.200 & & 238 & & -0.195 & & -0.214 & & 0.029 \\
\hline MLEV & & & & 0.102 & & 0.208 & & 263 & & -0.439 & & -0.298 & & -0.006 \\
\hline DMAT & & & & & & 0.137 & & 234 & & 0.064 & & 0.074 & & 0.100 \\
\hline SIZE & & & & & & & & 112 & & -0.081 & & 0.033 & & 0.002 \\
\hline TANG & & & & & & & & & & -0.168 & & -0.048 & & 0.344 \\
\hline GROWTH & & & & & & & & & & & & 0.399 & & 0.033 \\
\hline \multirow[t]{2}{*}{ PROFIT } & & & & & & & & & & & & & & -0.021 \\
\hline & MLEV & DMAT & CRTINTI & INTLDEBT & NRBLOAN & STKOPEN & CREDIT & STOCK & GDP & INFL & COMMON & LEGAL & IND & UAI \\
\hline \multicolumn{15}{|c|}{ Panel B: Capital structure and country-level variables } \\
\hline BLEV & 0.884 & 0.173 & 0.008 & -0.015 & 0.037 & -0.148 & 0.002 & -0.098 & -0.046 & $-\mathbf{0 . 0 1 4}$ & $-\mathbf{0 . 0 1 8}$ & -0.014 & -0.099 & -0.004 \\
\hline MLEV & & 0.102 & 0.058 & 0.035 & 0.063 & $-\mathbf{0 . 1 3 0}$ & 0.022 & -0.147 & $-\mathbf{0 . 0 2 8}$ & -0.037 & -0.055 & -0.021 & -0.142 & 0.023 \\
\hline DMAT & & & $-\mathbf{0 . 0 8 7}$ & -0.058 & -0.096 & -0.079 & $-\mathbf{0 . 1 7 3}$ & -0.091 & $-\mathbf{0 . 1 7 7}$ & 0.016 & 0.101 & -0.050 & 0.184 & -0.051 \\
\hline CRTINTI & & & & 0.877 & 0.849 & 0.456 & 0.048 & 0.170 & 0.026 & 0.046 & 0.077 & -0.026 & -0.104 & -0.134 \\
\hline INTLDEBT & & & & & 0.480 & 0.443 & -0.051 & 0.115 & 0.054 & 0.005 & 0.071 & -0.024 & 0.006 & -0.086 \\
\hline NRBLOAN & & & & & & 0.278 & 0.154 & 0.198 & -0.020 & 0.154 & 0.073 & -0.020 & -0.220 & -0.169 \\
\hline STKOPEN & & & & & & & -0.081 & 0.273 & 0.142 & 0.131 & 0.087 & -0.065 & 0.203 & 0.079 \\
\hline CREDIT & & & & & & & & 0.620 & 0.677 & -0.404 & -0.071 & 0.610 & -0.450 & -0.037 \\
\hline STOCK & & & & & & & & & 0.271 & -0.286 & 0.393 & 0.479 & -0.007 & -0.479 \\
\hline GDP & & & & & & & & & & -0.207 & -0.509 & 0.499 & -0.403 & 0.556 \\
\hline INFL & & & & & & & & & & & -0.105 & -0.323 & 0.167 & 0.165 \\
\hline COMMON & & & & & & & & & & & & 0.168 & 0.477 & -0.770 \\
\hline LEGAL & & & & & & & & & & & & & 0.018 & -0.123 \\
\hline IND & & & & & & & & & & & & & & -0.201 \\
\hline
\end{tabular}

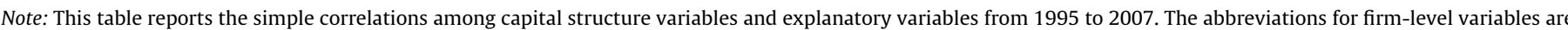

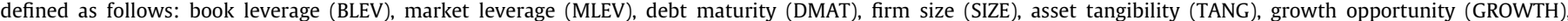

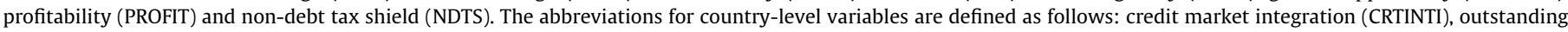

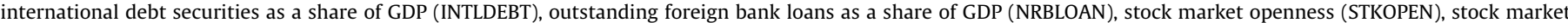

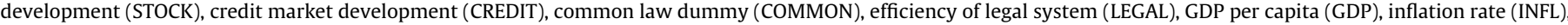

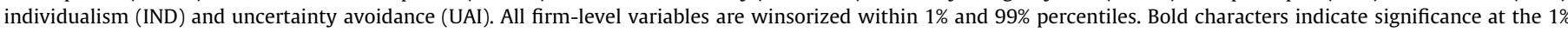
level.

can shift firms' financing to debt and equity, respectively. Not surprisingly, financial integration (presumably via increased financing options and reduced cost of capital) helps firms to obtain more external funds, presented as a propensity to take more debt or equity finance. The economic magnitude of the effect is reasonably high as well. A one standard deviation increase in credit (equity) market integration will lead to a 0.017 (0.030) unit increase (decrease) in the leverage ratio of the typical firm. To better understand the magnitude, we consider two countries in the sample, one of which has a high level of integration and the other a low level. For credit market integration (CRTINTI), the country with the greatest value is Argentina with 0.250 and India the smallest at 0.027. The estimate in Model 1 implies that if India's integration degree becomes identical to that of Argentina, everything else being equal, its average leverage ratio would roughly rise by 0.059 (5.9\%). This equals to a $20.6 \%$ increase in the average leverage of $28.5 \%$ for India. Similarly, consider two polar countries with the highest and lowest average STKOPEN values, which are South Africa with 0.996 and India with 0.422 , respectively. The statistics indicate that there is a gap of around $0.062(6.2 \%)$ in average leverage between these two countries, arising from the difference in stock market openness. In disaggregated Models 2 and 4, we find a significant and positive relation between foreign bank loans (NRBLOAN) and leverage at the $1 \%$ level, suggesting that greater penetration of the banking system by foreign banks appears to act as a catalyst for increased leverage. The result is consistent with Giannetti and Ongena (2009), where the authors find that foreign bank lending has increased corporate leverage in Eastern European economies. However, we do not find a significant relation between international debt issues (INTLDEBT) and leverage.

Models 5 and 6 of Table 4 show that, on explaining debt maturity, the coefficient on foreign bank loans (NRBLOAN) is negative at the $10 \%$ level, while those on overall integration (CRTINTI) and international debt (INTLDEBT) are insignificant. The evidence is supportive of $\mathrm{H} 2 \mathrm{a}$, albeit not overwhelming. The implications, when combined with the earlier findings, are that greater openness to foreign banks leads to more, but shorter dated, debt being taken on. This is consistent with the findings of Ağca et al. (2007), who find that greater credit market openness has led to higher leverage but shorter debt maturity in emerging economies. Consistent with our expectation, the institutional weakness of emerging economies, such as poor legal protection of creditors and informational opacity, makes foreign banks refrain from signing long-term debt contracts with local firms. We find evidence for H2b: stock market openness (STKOPEN) has a negative impact on debt maturity at the $1 \%$ level, suggesting the increased use of equity as an alternative to long-term debt.

Our results on control variables are quite consistent with relevant theories and empirical studies. As shown in Table 4, corporate leverage is positively associated with firm size (SIZE) and asset tangibility (TANG), and negatively associated with growth opportunity (GROWTH), profitability (PROFIT) and non-debt tax shields (NDTS). The results indicate that larger firms with more tangible assets are able to borrow more because they have a lower probability of bankruptcy, lower costs in the event of bankruptcy and provide more collateral to lenders relative to other firms. Firms use less leverage when they are more profitable and have better growth opportunities. This agrees with the theoretical arguments of information asymmetries between insiders and outsiders of firms (Myers and Majluf, 1984) and the underinvestment problems (Myers, 1977), respectively. The negative association between nondebt tax shields and leverage suggests that the use of debt finance as tax shields becomes less necessary when firms have other alternatives. For country-level control variables, we find that leverage is positively related to stock market development (STOCK), whereas more often than not the negative relation is expected. This sug- 
Table 4

Determinants of corporate leverage and debt maturity.

\begin{tabular}{|c|c|c|c|c|c|c|}
\hline \multirow[t]{3}{*}{ Explanatory variables } & \multicolumn{6}{|c|}{ Dependent variables } \\
\hline & \multicolumn{2}{|l|}{ BLEV } & \multicolumn{2}{|l|}{ MLEV } & \multicolumn{2}{|l|}{ DMAT } \\
\hline & Model 1 & Model 2 & Model 3 & Model 4 & Model 5 & Model 6 \\
\hline \multicolumn{7}{|c|}{ Financial integration variables } \\
\hline CRTINTI & $\begin{array}{l}0.268^{* * *} \\
(5.09)\end{array}$ & & $\begin{array}{l}0.319^{* * * *} \\
(6.04)\end{array}$ & & $\begin{array}{l}-0.108 \\
(-1.18)\end{array}$ & \\
\hline INTLDEBT & & $\begin{array}{l}-0.024 \\
(-0.51)\end{array}$ & & $\begin{array}{l}-0.005 \\
(-0.10)\end{array}$ & & $\begin{array}{l}0.085 \\
(0.90)\end{array}$ \\
\hline NRBLOAN & & $\begin{array}{l}0.251^{* * *} \\
(6.38)\end{array}$ & & $\begin{array}{l}0.250^{* * *} \\
(6.17)\end{array}$ & & $\begin{array}{l}-0.115^{*} \\
(-1.65)\end{array}$ \\
\hline STKOPEN & $\begin{array}{l}-0.128^{* * *} \\
(-12.12)\end{array}$ & $\begin{array}{l}-0.145^{* * *} \\
(-13.31)\end{array}$ & $\begin{array}{l}-0.152^{* * *} \\
(-14.04)\end{array}$ & $\begin{array}{l}-0.168^{* * *} \\
(-14.91)\end{array}$ & $\begin{array}{l}-0.057^{* * *} \\
(-2.81)\end{array}$ & $\begin{array}{l}-0.060^{* *} \\
(-2.78)\end{array}$ \\
\hline \multicolumn{7}{|l|}{ Firm-level variables } \\
\hline SIZE & $\begin{array}{l}0.021^{* * * *} \\
(14.35)\end{array}$ & $\begin{array}{l}0.021^{* * *} \\
(14.32)\end{array}$ & $\begin{array}{l}0.016^{* * *} \\
(11.15)\end{array}$ & $\begin{array}{l}0.016^{* * *} \\
(11.06)\end{array}$ & $\begin{array}{l}0.048^{* * *} \\
(20.99)\end{array}$ & $\begin{array}{l}0.048^{\text {**** }} \\
(20.96)\end{array}$ \\
\hline TANG & $\begin{array}{l}0.148^{* * * *} \\
(12.03)\end{array}$ & $\begin{array}{l}0.154^{* * * *} \\
(12.44)\end{array}$ & $\begin{array}{l}0.170^{* * * *} \\
(13.62)\end{array}$ & $\begin{array}{l}0.175^{* * *} \\
(13.91)\end{array}$ & $\begin{array}{l}0.308^{* * * *} \\
(17.30)\end{array}$ & $\begin{array}{l}0.310^{* * * *} \\
(17.22)\end{array}$ \\
\hline GROWTH & $\begin{array}{l}-0.015^{* * *} \\
(-6.43)\end{array}$ & $\begin{array}{l}-0.014^{* * *} \\
(-6.08)\end{array}$ & $\begin{array}{l}-0.060^{* * *} \\
(-30.58)\end{array}$ & $\begin{array}{l}-0.059^{* * *} \\
(-29.97)\end{array}$ & $\begin{array}{l}0.017^{* * *} \\
(3.73)\end{array}$ & $\begin{array}{l}0.018^{* * * *} \\
(3.79)\end{array}$ \\
\hline PROFIT & $\begin{array}{l}-0.396^{* * * *} \\
(-19.10)\end{array}$ & $\begin{array}{l}-0.404^{* * *} \\
(-19.38)\end{array}$ & $\begin{array}{l}-0.416^{* * *} \\
(-21.07)\end{array}$ & $\begin{array}{l}-0.424^{* * *} \\
(-21.22)\end{array}$ & $\begin{array}{l}0.055 \\
(1.49)\end{array}$ & $\begin{array}{l}0.050 \\
(1.34)\end{array}$ \\
\hline NDTS & $\begin{array}{l}-0.266^{* * * *} \\
(-3.49)\end{array}$ & $\begin{array}{l}-0.282^{* * * *} \\
(-3.68)\end{array}$ & $\begin{array}{l}-0.518^{* * *} \\
(-6.76)\end{array}$ & $\begin{array}{l}-0.533^{* * *} \\
(-6.90)\end{array}$ & $\begin{array}{l}0.244^{* * *} \\
(2.17)\end{array}$ & $\begin{array}{l}0.242^{* *} \\
(2.12)\end{array}$ \\
\hline \multicolumn{7}{|l|}{ Country-level variables } \\
\hline CREDIT & $\begin{array}{l}-0.005 \\
(-0.33)\end{array}$ & $\begin{array}{l}-0.001 \\
(-0.02)\end{array}$ & $\begin{array}{l}-0.035^{* *} \\
(-2.22)\end{array}$ & $\begin{array}{l}-0.038^{* *} \\
(-2.32)\end{array}$ & $\begin{array}{l}-0.029 \\
(-1.01)\end{array}$ & $\begin{array}{l}-0.011 \\
(-0.36)\end{array}$ \\
\hline STOCK & $\begin{array}{l}0.033^{* * *} \\
(4.78)\end{array}$ & $\begin{array}{l}0.023^{* * *} \\
(3.32)\end{array}$ & $\begin{array}{l}0.035^{* * * *} \\
(5.34)\end{array}$ & $\begin{array}{l}0.034^{* * * *} \\
(4.84)\end{array}$ & $\begin{array}{l}-0.013 \\
(-0.93)\end{array}$ & $\begin{array}{l}-0.017 \\
(-1.26)\end{array}$ \\
\hline GDP & $\begin{array}{l}0.031^{* * * *} \\
(2.67)\end{array}$ & $\begin{array}{l}0.042^{* * * *} \\
(3.43)\end{array}$ & $\begin{array}{l}0.029^{* *} \\
(2.34)\end{array}$ & $\begin{array}{l}0.021 \\
(1.64)\end{array}$ & $\begin{array}{l}-0.045^{* *} \\
(-2.15)\end{array}$ & $\begin{array}{l}-0.029 \\
(-1.31)\end{array}$ \\
\hline INFL & $\begin{array}{l}0.110^{* * * *} \\
(5.25)\end{array}$ & $\begin{array}{l}0.194^{* * *} \\
(8.00)\end{array}$ & $\begin{array}{l}0.079^{* * *} \\
(4.59)\end{array}$ & $\begin{array}{l}0.102^{* * * *} \\
(4.98)\end{array}$ & $\begin{array}{l}0.059^{*} \\
(1.72)\end{array}$ & $\begin{array}{l}0.063 \\
(1.50)\end{array}$ \\
\hline COMMON & $\begin{array}{l}0.129^{* * *} \\
(5.38)\end{array}$ & $\begin{array}{l}-0.218^{* * *} \\
(-2.92)\end{array}$ & $\begin{array}{l}0.110^{* * * *} \\
(4.78)\end{array}$ & $\begin{array}{l}-0.131^{* *} \\
(-2.06)\end{array}$ & $\begin{array}{l}0.305^{* * *} \\
(7.83)\end{array}$ & $\begin{array}{l}-0.153 \\
(-1.46)\end{array}$ \\
\hline LEGAL & $\begin{array}{l}-0.052^{\text {**** }} \\
(-4.35)\end{array}$ & $\begin{array}{l}-0.050^{* * * *} \\
(-4.11)\end{array}$ & $\begin{array}{l}-0.038^{* * *} \\
(-3.31)\end{array}$ & $\begin{array}{l}-0.029^{* *} \\
(-2.49)\end{array}$ & $\begin{array}{l}0.005 \\
(0.27)\end{array}$ & $\begin{array}{l}-0.003 \\
(-0.17)\end{array}$ \\
\hline IND & $\begin{array}{l}0.001 \\
(0.02)\end{array}$ & $\begin{array}{l}0.001 \\
(0.54)\end{array}$ & $\begin{array}{l}0.001 \\
(0.31)\end{array}$ & $\begin{array}{l}0.001 \\
(1.22)\end{array}$ & $\begin{array}{l}-0.002^{* *} \\
(-2.01)\end{array}$ & $\begin{array}{l}-0.002^{* *} \\
(-2.34)\end{array}$ \\
\hline UAI & $\begin{array}{l}-0.009^{* * *} \\
(-4.84)\end{array}$ & $\begin{array}{l}-0.009^{* * *} \\
(-4.99)\end{array}$ & $\begin{array}{l}-0.006^{* * *} \\
(-4.01)\end{array}$ & $\begin{array}{l}-0.006^{* * *} \\
(-3.49)\end{array}$ & $\begin{array}{l}-0.006^{* *} \\
(-2.09)\end{array}$ & $\begin{array}{l}-0.006^{* *} \\
(-2.37)\end{array}$ \\
\hline Constant & $\begin{array}{l}0.648^{* * *} \\
(3.76)\end{array}$ & $\begin{array}{l}0.583^{* * *} \\
(3.37)\end{array}$ & $\begin{array}{l}0.509^{* * * *} \\
(3.47)\end{array}$ & $\begin{array}{l}0.468^{* * * *} \\
(3.17)\end{array}$ & $\begin{array}{l}0.456^{*} \\
(1.84)\end{array}$ & $\begin{array}{l}0.459^{*} \\
(1.85)\end{array}$ \\
\hline F-test & $42.88^{* * * *}$ & $42.74^{* * * *}$ & $94.19^{* * *}$ & $90.42^{* * *}$ & $54.27^{* * * *}$ & $54.26^{* * * *}$ \\
\hline Adjusted $R$-square & 0.187 & 0.187 & 0.303 & 0.300 & 0.194 & 0.195 \\
\hline Number of observations & 32,084 & 30,959 & 31,957 & 30,835 & 30,544 & 29,459 \\
\hline
\end{tabular}

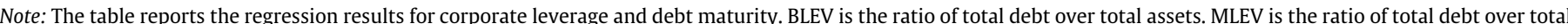

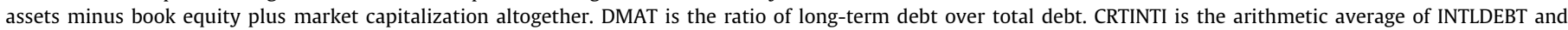

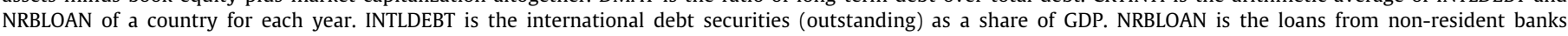

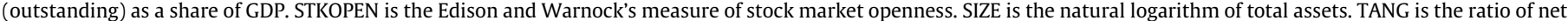

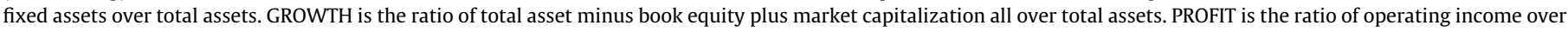

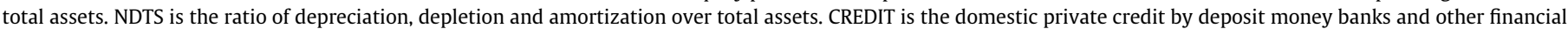

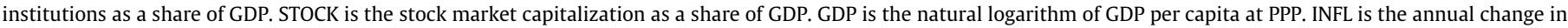

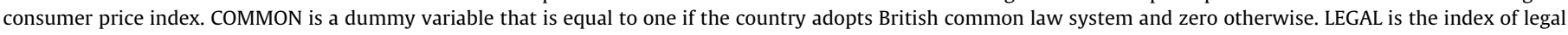

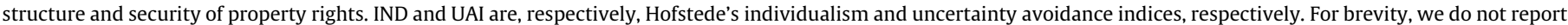
the estimates of country, industry and year dummy variables. Standard errors are clustered by firms. The values of $t$-statistics are reported in brackets.

**** Stand for significance at the $1 \%$ level.

** Stand for significance at the $5 \%$ level.

* Stand for significance at the $10 \%$ level.

gests that stock markets affect information transmission that is useful to creditors (Demirgüç-Kunt and Maksimovic, 1999), so firms are able to obtain more long-term credit. Leverage seems to be higher in countries with high GDP per capita (GDP) and inflation rate (INFL). A more efficient legal system (LEGAL) leads to lower leverage, while the effect of the common law dummy is mixed. Consistent with the argument of Gleason et al. (2000), leverage is negatively associated with the level of uncertainty avoidance (UAI) of a country. The possible reason is that in countries with high uncertainty avoidance, people prefer certainty and security. Thus, managers use lower levels of debt in their capital structure because financing assets with greater debt increases the exposure to bankruptcy risk.

In the debt maturity regressions, the ratio of long-term debt to total debt is higher for firms with larger size, greater asset tangibility and brighter growth opportunities. Our findings are in line with Schmukler and Vesperoni (2006), Ağca et al. (2007) and Fan et al. (2010). We also find that GDP per capita and individualism have negative and positive effects on debt maturity, respectively.

The $F$-tests of all model specifications indicate that explanatory variables are jointly significant at the $1 \%$ level. The adjusted $R$ squares are at levels (ranging from $18.7 \%$ to $30.3 \%$ ), comparable 
Table 5

Interactive effects of financial integration on corporate leverage and debt maturity.

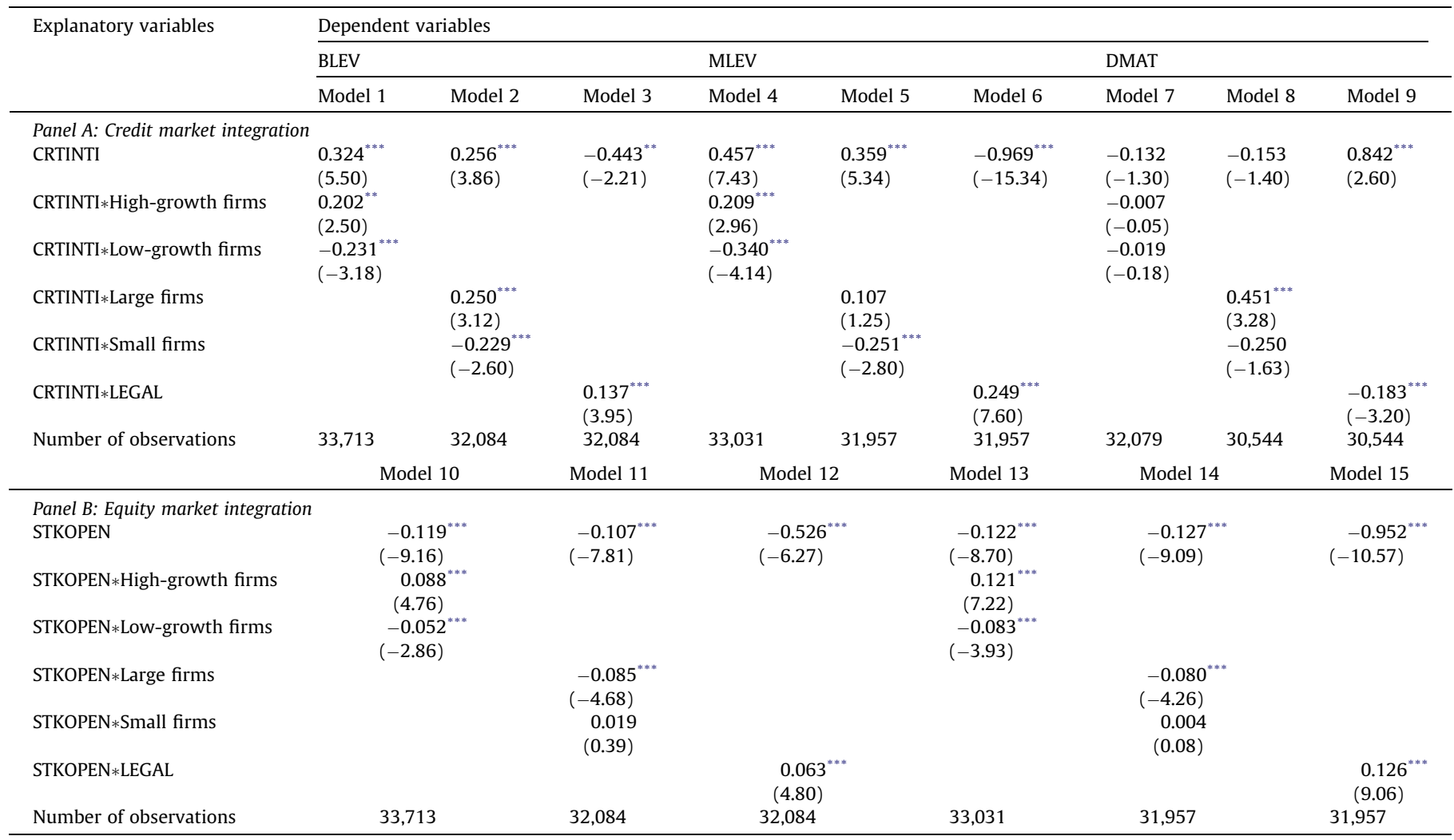

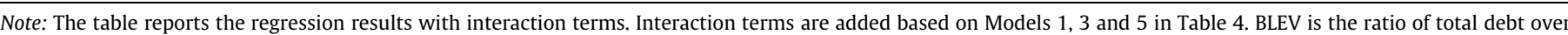

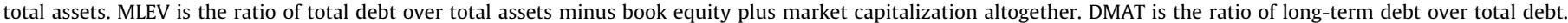

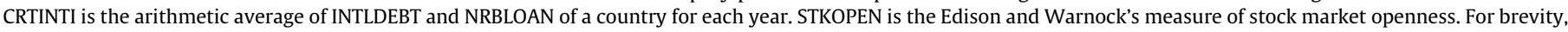

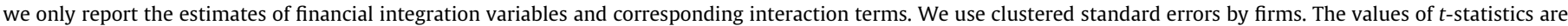
reported in brackets.

*, Stand for significance at the $10 \%$ level.

*** Stand for significance at the $1 \%$ level.

** Stand for significance at the $5 \%$ level.

to other studies. Hence, our models have some ability to explain the variation of capital structure decisions in emerging economies.

\subsection{The interactive effects of financial integration on corporate financing choices}

To interact with firm characteristics, we multiply CRTINTI and STKOPEN by dummy variables for large firms, small firms, highgrowth firms and low-growth firms, respectively. Large and highgrowth firms are those with an average value of firm size (SIZE) and growth opportunity (GROWTH) at the top 25\% percentile, while small and low-growth firms are those with a value at the low $25 \%$ percentile. $^{8}$ To interact with law, we directly multiply integration variables by the efficiency of the legal system (LEGAL).

Table 5 reports the regression results of financial integration and interaction terms. The results in Model 1 and Model 4 indicate that the positive impact of overall credit market integration (CRTINTI) on leverage is significant for high-growth firms, with coefficients 0.202 and 0.209 at the $5 \%$ and the $1 \%$ levels, respectively. By contrast, interactions with low-growth firms present negative coefficients -0.231 and -0.340 at the $1 \%$ level. This is consistent with the notion of H3a that increased credit market integration

\footnotetext{
${ }^{8}$ To obtain econometrically sound specifications, we include size group and growth group dummy variables in the corresponding interaction regressions instead of the original variables of firm size and growth opportunity.
}

brings necessary debt finance to high- growth firms, while the effect is not pronounced for low-growth firms. Against H3b, the results of Models 10 and 13 indicate that the negative effect of STKOPEN is weakened for high-growth firms, with positive coefficients 0.088 and 0.121 at the $1 \%$ level. This is likely due to the fact that high-growth firms have tilted towards the use of equity, thus attenuating the effect of equity market integration. From Model 7 for debt maturity, we do not find evidence for $\mathrm{H} 4$.

The results in Models 2 and 5 show that the positive impact of CRTINTI on leverage is stronger for large firms with a positive coefficient of 0.250 at the $1 \%$ level, but is severely attenuated for small firms with negative coefficients -0.229 and -0.251 at the $1 \%$ level. Models 11 and 14 show that the negative impact of STKOPEN on leverage is particularly significant for large firms with coefficients -0.085 and -0.080 at the $1 \%$ level, while it is not significant for small firms. Consistent with H5a and H5b, large firms seem to have advantages in accessing external debt and equity financing when financial integration rises to higher levels. Turning to debt maturity, Model 8 shows that the general effect of CRTINTI remains insignificant, which is the same as the baseline result. However, this effect varies significantly with firm size. A positive coefficient of 0.451 at the $1 \%$ level is observed for the interaction term with the large firm dummy variable, while small firms seem less sensitive to integration. Consistent with H6, the informational advantage of large firms facilitates their ability to borrow more longterm funds. 
We find evidence for H7a in Models 3 and 6, showing that the positive impact of CRTINTI increases with legal efficiency. To illustrate this point, we use the coefficient estimates in Model 3 and show the total effect of credit market integration as $(-0.443+0.137 \times \bar{L}) \times$ CRTINTI $_{c, t-1}$, where $\bar{L}$ is the mean of the efficiency of legal system (LEGAL). For a one-unit increase in the level of credit market integration (CRTINTI), the difference in the general level of legal efficiency makes the effect of CRTINTI quite different between the subsamples. There seems to exist a threshold of $\bar{L}$ (around 3.23 in this case), above which the effect of CRTINTI is positive but negative otherwise. Thus, credit market integration can be effective for debt financing only if a country has attained a threshold level of legal efficiency. A similar implication can be obtained from the results of Model 6. However, the results in Models 9, 12 and 15 cannot support H7b and H8. For example, we find that a sound legal system discourages local firms from issuing more equity when equity market integration deepens. The possible reasons for the disagreement are twofold. First, a limited number of countries and a narrow variation in the LEGAL variable reduce the freedom to test the interactive effects. Second, different institutional dimensions can overlap each other. The interactions of parallel institutional features with financial integration could work on corporate financing in contradictory ways. In our case, countries with more efficient legal systems may have better-developed financial intermediaries and markets as well (e.g., La Porta et al., 1997; Beck et al., 2003). It is likely that firms from countries with more developed domestic markets would be less sensitive to financial integration compared with firms from countries with underdeveloped domestic markets.

\subsection{Robustness checks}

We conduct additional estimations to check the robustness of the findings in Tables 4 and 5. First, we adopt alternative measures of financial integration. We use gross stocks of portfolio debt investment over GDP to measure credit market integration, and we use gross stocks of portfolio equity investment over GDP to measure equity market integration. The measures draw upon the updated and extended version of the External Wealth of Nations Mark II database developed by Lane and Milesi-Ferretti (2007). Second, with the concern that our results are driven by sample bias, we exclude Taiwanese firms, the number of which is more than a quarter of the sample. Third, we re-estimate all regression models using 2-year lagged explanatory variables. The results of these checks are largely consistent with the earlier findings on the direct and interactive effects of financial integration. Only minor variations are found. We find that the negative effects of credit and equity market integration on debt maturity are not persistently significant across robustness checks, while other variations do not change our conclusions. We do not report the results of robustness checks, to reserve space, but they are readily available.

\section{Conclusions}

In this paper, we aim to better understand how international financial integration affects corporate leverage and debt maturity structures in emerging economies. For the purpose, we attempt to address empirical shortcomings of previous studies on financial integration and corporate financing. We consider both credit market integration and equity market integration over time, and we control for a variety of determining factors. We construct a large panel set containing 4477 public firms from 24 countries during 1995-2007. We find that increased credit and equity market integration lead to greater use of debt and equity financing, respectively. The results reflect the economic benefits brought by financial integration, such as expanded financing options and decreased costs of capital. These channels may individually or collectively work on corporate financing choices. The economic magnitude of the effect is reasonably high as well. On top of the impact of financial integration, we also confirm the effects of some well-known determining factors, which is an important by-product of the paper.

Furthermore, the effect seems to be more pronounced for highgrowth firms than for low-growth firms on the credit side. In this sense, policy makers should encourage financial integration because it will help local firms raise external funds for their investment projects and contributes to the growth of these firms in the long run. It is equally noteworthy that the alleged benefits of financial integration do not seem to be a "free lunch". Specifically, during the financial integration process, large firms seem to obtain more debt (especially long-term debt) and issue more equity than small firms, and creditors lend more to firms in countries with more efficient legal systems. The results present a clear picture of how financial integration generates good outcomes. Lower monitoring costs, more transparent information and better creditor and shareholder protection enable companies to better enjoy financial integration. In this regard, our results have useful implications to corporate managers and policy makers.

The results reported in this paper leave a few unanswered questions for future research. One question is: How long before the opening of a country market affects corporate financing behavior. For example, financial integration might not function immediately after the official market opening. The panel analysis in this paper may only provide implications about the overall integration process, without addressing the timing of financial integration taking effect. Future works could start by searching for effective opening dates and then examining how capital structure responds to the change. Another related question is to ask at what stage of integration the corporate financing behavior is impacted. Indeed, integration of a country may keep at a relatively high level in some periods, while drop to a low level in other periods. For example, some countries reinstated capital controls after the 1998 Asian financial crisis to stabilize domestic markets. Hence, we would expect that the effect of financial integration on capital structure is less significant and smaller in magnitude in the post-crisis period. Future studies could also shed more light on firm-level financial integration, which would offer us a closer look at integration effects. Relevant integration measures could be calculated using foreign assets, foreign sales, commercial loans from non-resident banks and cross-listing data.

\section{Acknowledgments}

The authors acknowledge helpful comments from Colm Kearney, Thomas Lagoarde-Segot, two anonymous referees, as well as session participants at the 2009 INFINITI Conference on International Finance held at Trinity College Dublin, Ireland, the 2009 Journal of Corporate Finance Conference on Corporate Finance and Governance in Emerging Markets held at Peking University, China and the 2010 Annual Meeting of the Midwest Finance Association in Las Vegas, USA. Zhang acknowledges support from the Trinity College Graduate Studies Award Scheme.

\section{References}

Abad, P., Chuliá, H., Gómez-Puig, M., 2010. EMU and European government bond market integration. Journal of Banking and Finance 34, 2851-2860.

Ağca, Ş., De Nicolò, G., Detragiache, E., 2007. Financial reforms, financial openness, and corporate borrowing: international evidence. Working paper 07/186, IMF.

Akram, Q.F., Rime, D., Sarno, L., 2009. Does the law of one price hold in international financial markets? Evidence from tick data. Journal of Banking and Finance 33, 1741-1754. 
Bae, K.H., Bailey, W., Mao, C.X., 2006. Stock market liberalization and the information environment. Journal of International Money and Finance 25, 404-428.

Bailey, W., Chung, Y.P., Kang, J.K., 1999. Foreign ownership restrictions and equity price premiums: what drives the demand for cross-border investments? Journal of Financial and Quantitative Analysis 34, 489-511.

Barclay, M.J., Smith, C.W., 1995. The maturity structure of corporate debt. Journal of Finance 50, 609-631.

Beck, T., Demirgüç-Kunt, A., Levine, R., 2003. Law and finance. Why does legal origin matter? Journal of Comparative Economics 31, 653-675.

Beck, T., Demirgüç-Kunt, A., Maksimovic, V., 2008. Financing patterns around the world: are small firms different? Journal of Financial Economics 89, 467-487.

Beck, T., Demirgüç-Kunt, A., 2009. Financial institutions and markets across countries and over time - data and analysis. Working paper series \#4943, World Bank Policy Research.

Bekaert, G., Harvey, C.R., 2000. Foreign speculators and emerging equity markets. Journal of Finance 55, 565-613.

Bekaert, G., Harvey, C.R., Lumsdaine, R.L., 2002. Dating the integration of world equity markets. Journal of Financial Economics 65, 203-247.

Bekaert, G., Harvey, C.R., Lundblad, C., 2001a. Emerging equity markets and economic development. Journal of Development Economics 66, 465504.

Bekaert, G., Harvey, C.R., Lundblad, C., 2001b. Does financial liberalization spur growth? Working paper 8245, National Bureau of Economic Research, Cambridge, MA.

Berger, A.N., Klapper, L.F., Udell, G.F., 2001. The ability of banks to lend to informationally opaque small businesses. Journal of Banking and Finance 25, 2127-2167.

Booth, L., Aivazian, V., Demirgüç-Kunt, A., Maksimovic, V., 2001. Capital structures in developing countries. Journal of Finance 56, 87-130.

Brounen, D., De Jong, A., Koedijk, K., 2006. Capital structure policies in Europe: survey evidence. Journal of Banking and Finance 30, 1409-1442.

Chambet, A., Gibson, R., 2008. Financial integration, economic instability and trade structure in emerging markets. Journal of International Money and Finance 27. 654-675.

Chari, A., Henry, P.B., 2004. Risk sharing and asset prices: evidence from a natural experiment. Journal of Finance 59, 1295-1324.

Christiansen, C., Ranaldo, A., 2009. Extreme coexceedances in new EU member states' stock markets. Journal of Banking and Finance 33, 1048-1057.

Christoffersen, P., Chung, H., Errunza, V., 2006. Size matters: the impact of financial liberalization on individual firms. Journal of International Money and Finance 25, 1296-1318.

Claessens, S., Demirgüç-Kunt, A., Huizinga, H., 2001. How does foreign entry affect domestic banking markets? Journal of Banking and Finance 25, 891911.

DeAngelo, H., Masulis, R.W., 1980. Optimal capital structure under corporate and personal taxation. Journal of Financial Economics 8, 139-178.

De Jong, A., Kabir, R., Nguyen, T.T., 2008. Capital structure around the world: the roles of firm- and country-specific determinants. Journal of Banking and Finance 32, 1954-1969.

Demirgüç-Kunt, A., Maksimovic, V., 1996. Stock market development and financing choices of firms. World Bank Economic Review 10, 341-369.

Demirgüç-Kunt, A., Maksimovic, V., 1999. Institutions, financial markets, and firm debt maturity. Journal of Financial Economics 54, 295-336.

Diamond, D.W., 1991. Debt maturity and liquidity risk. Quarterly Journal of Economics 106, 709-737.

Diamond, D.W., 1993. Seniority and maturity of debt contracts. Journal of Financial Economics 33, 341-368.

Diamond, D.W., 2004. Presidential address, committing to commit: short-term debt when enforcement is costly. Journal of Finance 59, 1447-1479.

Doidge, C., Karolyi, G.A., Stulz, R.M., 2004. Why are foreign firms listed in the US worth more? Journal of Financial Economics 71, 205-238.

Edison, H.J., Warnock, F.E., 2003. A simple measure of the intensity of capital controls. Journal of Empirical Finance 10, 81-103.

Errunza, V.R., Miller, D.P., 2000. Market segmentation and the cost of capital in international equity markets. Journal of Financial and Quantitative Analysis 35, $577-600$.

Fan, J.P.H., Titman, S., Twite, G., 2010. An international comparison of capital structure and debt maturity choices. Working paper, <http://ssrn.com/ abstract $=423483>$.
Giannetti, M., 2003. Do better institutions mitigate agency problems? Evidence from corporate finance choices. Journal of Financial and Quantitative Analysis $38,185-212$.

Giannetti, M., Guiso, L., Jappelli, T., Padula, M., Pagano, M., 2002. Financial market integration, corporate financing and economic growth. European Economy, Economic Papers \#179.

Giannetti, M., Ongena, S., 2009. Financial integration and firm performance Evidence from foreign bank entry in emerging markets. Review of Finance 13 181-223.

Gleason, K.C., Mathur, L.K., Mathur, I., 2000. The interrelationship between culture capital structure, and performance. Evidence from European retailers. Journal of Business Research 50, 185-191.

Gupta, N., Yuan, K., 2009. On the growth effect of stock market liberalizations. Review of Financial Studies 22, 4715-4752.

Henry, P.B., 2000a. Stock market liberalization, economic reform, and emerging market equity prices. Journal of Finance 55, 529-564.

Henry, P.B., 2000b. Do stock market liberalizations cause investment booms? Journal of Financial Economics 58, 301-334.

Hofstede, G., 2001. Culture's Consequences: Comparing Values, Behaviors, Institutions and Organizations Across Nations. Sage Publications, Thousand Oaks, CA

Kang, J.K., Stulz, R.M., 1997. Why is there a home bias? An analysis of foreign portfolio equity ownership in Japan. Journal of Financial Economics 46, 3-28.

Kim, E.H., Singal, V., 2000. Stock market opening: experience of emerging economies. Journal of Business 73, 25-66.

Lane, P.R., Milesi-Ferretti, G.M., 2007. The external wealth of nations mark II: revised and extended estimates of foreign assets and liabilities, 1970-2004. Journal of International Economics 73, 223-250.

La Porta, R., Lopez-de-Silanes, F., Shleifer, A., Vishny, R., 1997. Legal determinants of external finance. Journal of Finance 52, 1131-1150.

La Porta, R., Lopez-de-Silanes, F., Shleifer, A., Vishny, R., 1998. Law and finance. Journal of Political Economy 106, 1113-1155.

La Porta, R., Lopez-de-Silanes, F., Shleifer, A., Vishny, R., 2000. Investor protection and corporate governance. Journal of Financial Economics 58, 3-27.

Levine, R., 1996. Foreign banks, financial development, and economic growth. In: Claude, E.B. (Ed.), International Financial Markets. AEI Press, Washington, DC.

Merton, R.C., 1987. A simple model of capital market equilibrium with incomplete information. Journal of Finance 42, 483-510.

Mian, A., 2006. Distance constraints: the limits of foreign lending in poor economies. Journal of Finance 61, 1465-1505.

Mitton, T., 2006. Stock market liberalization and operating performance at the firm level. Journal of Financial Economics 81, 625-647.

Myers, S.C., 1977. Determinants of corporate borrowing. Journal of Financial Economics 5, 147-175

Myers, S.C., Majluf, N., 1984. Corporate financing and investment decisions when firms have information that investors do not have. Journal of Financial Economics 13, 187-221.

Obstfeld, M., 1998. The global capital market: benefactor or menace? Journal of Economic Perspectives 12, 9-30.

Patro, D.K., Wald, J.K., 2005. Firm characteristics and the impact of emerging market liberalizations. Journal of Banking and Finance 29, 1671-1695.

Pukthuanthong, K., Roll, R., 2009. Global market integration: an alternative measure and its application. Journal of Financial Economics 94, 214-232.

Qian, J., Strahan, P.E., 2007. How laws and institutions shape financial contracts: the case of bank loans. Journal of Finance 62, 2803-2834

Rajan, R.G., 1992. Insiders and outsiders: the choice between informed and arm's length debt. Journal of Finance 47, 1367-1400.

Rajan, G.R., Zingales, L., 1995. What do we know about capital structure? Some evidence from international data. Journal of Finance 50, 1421-1460.

Rajan, G.R., Zingales, L., 1998. Financial dependence and growth. American Economic Review 88, 559-586.

Schmukler, S.L., Vesperoni, E., 2006. Financial globalization and debt maturity in emerging economies. Journal of Development Economics 79, 183-207.

Stiglitz, J.E., Weiss, A., 1981. Credit rationing in markets with imperfect information. American Economic Review 71, 393-410.

Stulz, R.M., 1999. Globalization, corporate finance, and the cost of capital. Journal of Applied Corporate Finance 12, 8-25.

Yu, I.-W., Fung, K.-P., Tam, C.-S., 2010. Assessing financial market integration in Asia - equity markets. Journal of Banking and Finance 34, 2874-2885. 